\title{
Efektifitas Pijat Bayi terhadap Peningkatan Berat Badan pada Bayi Usia 0 - 3 Bulan
}

\author{
Effectiveness of Infant Massage on Weight Gain in Infants \\ Aged 0-3 Months
}

\author{
Dersy Elya $^{1, \otimes}$, M. Ridwan ${ }^{2}$, Yetty Anggraeni ${ }^{2}$ \\ ${ }^{1}$ Dinas Kesehatan Kabupaten Pesisir Barat, Provinsi Lampung, Indonesia \\ ${ }^{2}$ Jurusan Kebidanan, Politeknik Kesehatan Tanjung karang, Indonesia \\ ${ }^{凶}$ Corespondingauthor: iwansayad66@Gmail.com
}

\author{
Kata kunci: \\ Pijat bayi, \\ Peningkatanberat badan \\ bayi, \\ Usia 0-3 bulan.
}

Keyword:

Baby massage,

Baby weight gain,

Aged 0-3 months.

\begin{abstract}
Abstrak
Latar Belakang: Penyakit reproduksi yang banyak diderita oleh wanita Indonesia ialah mioma uteri. Jumlah kejadian penyakit ini di Indonesia menempati urutan kedua setelah kanker servik. Tujuan: Penelitian ini bertujuan untuk mengetahui hubungan antara usia ibu dan paritas dengan kejadian mioma uteri di Rumah Sakit Mardi Waluyo Metro tahun 2016. Metode:Penelitian ini menggunakan rancangan cross sectional. Sampel penelitian berjumlah 141 responden. Variabel independen penelitian adalah usia ibu dan paritas, sedangkan variabel dependen, yaitu mioma uteri.Analisis data menggunakan analisis univariat dan bivariat. Analisis bivariat menggunakan uji chi square. Hasil: Hasil penelitian menunjukkan terdapat hubungan usia ibu $(p=0,000)$ dan paritas $(p=0,000)$ dengan kejadian mioma uteri di Rumah Sakit Mardi Waluyo Metro. Simpulan:Usia ibu dan paritas menjadi faktor yang meningkatkan kejadian mioma uteri. Upaya pencegahan dan menurunkan kejadian mioma uteri perlu ditingkatkan dengan melakukan deteksi dini pada perempuan dengan usia dan paritas berisiko.
\end{abstract}

\begin{abstract}
s
Background: Increasing baby's growth and development can be done by providing stimulation, such as massage. Baby massage is beneficial to increase baby's weight. The monthly report of the Ganjar Agung Health Center in January-March 2017 contains an average of $14.7 \%$ of babies who do not gain weight. Purpose:The study aims to determine the effectiveness of infant massage on weight gain in infants aged 0-3 months in the Ganjar Agung Metro Barat Health Center in 2017.Methods:This study uses a pre-experimental design with non-equivalent control group design. The intervention given is baby massage. The research sample was all infants aged 0-3 months totaling 25 babies taken by consecutive sampling technique. Data analysis using paired t test. Results: The results showed a mean increase in baby's body weight after massage of 0.916 $\mathrm{kg}(S D 0.1214 \mathrm{~kg})$ and there was an effect of infant massage on weight gain in infants aged 0-3 $(p=0.000)$.Conclusion:The conclusion of the study is that infant massage can be one of the interventions to increase the baby's weight. Efforts to socialize baby massage programmatically need to be improved as one of the interventions to increase the growth (weight) of the baby.
\end{abstract}

Copyright $\odot 2018$ Jurnal Kesehatan Metro Sai Wawai. All rights reserved. 


\section{Pendahuluan}

Salah satu masalah yang sering dijumpai pada ibu menyusui ialah mereka merasa berat badan anaknya tidak naik-naik atau begitu-begitu saja. Masalah ini bisa muncul kapan saja selama periode pemberian ASI. Ketika orang tua mengalami kondisi tersebut, biasanya mereka mengambil jalan pintas dengan cara memberi makanan tambahan kepada anaknya seperti susu formula karena merasa bahwa pemberian ASI yang ia lakukan tidak mampu meningkatkan berat badan anaknya. Berat badan lahir merupakan hasil interaksi dari berbagai faktor melalui suatu proses yang berlangsung selama berada dalam kandungan. Faktor-faktor yang dapat mempengaruhi berat badan lahir meliputi faktor lingkungan internal yaitu umur ibu, jarak kelahiran, paritas, kadar hemoglobin, status gizi ibu hamilan faktor penggunaan sarana kesehatan yang berhubungan frekuensi pemeriksaan kehamilan atau Antenatal Care (ANC) (Manuaba, 2010).

Salah satu faktor dalam meningkatkan pertumbuhan dan perkembangan bayi adalah dengan memberikan stimulasi (Narendra \& Soetjiningsih, 2008). Pijat bayi memiliki banyak sekali manfaat salah satunya adalah meningkatkan berat badan bayi, hal itu dikarenakan pada bayi yang dipijat akan mengalami peningkatan tonus nervus vagus (saraf otak ke-10) yang akan menyebabkan peningkatan kadar enzim penyerapan gastrin dan insulin, dengan demikian penyerapan makanan akan menjadi lebih baik itulah sebabnya mengapa berat badan bayi yang dipijat akan meningkat lebih banyak dari pada yang tidak di pijat (Roesli, 2011).

Touch therapy atau massage (pemijatan) merupakan salah satu teknik yang mengombinasikan manfaat fisik sentuhan manusia dengan manfaat emosional seperti ikatan batin (bonding). Aktivitas pijat menimbulkan suatu kontak antara anak dan orangtua. Anak akan merasa tenteram dan nyaman karena dampak psikologis dari pemijatan ini adalah menyatakan rasa sayang. Terlebih lagi bila pemijatan dilakukan dengan memberi penghangat sehiggga secara fisik badan anak akan terasa hangat, sedangkan secara kejiwaan, hubungan anak dan orangtua bertambah intim (Pratyahara, 2012).

Pemijatan dapat mengoptimalkan tumbuh kembang bayi dengan resiko tinggi, yakni bayi-bayi yang dalam proses kehamilan dan kelahirannya mempunyai faktor-faktor resiko yang dapat mengganggu tumbuh kembangnya. Misalnya, berat lahir kurang dari 2000 gram. Pijat bayi dapat digolongkan sebagai aplikasi stimulasi sentuhan karena dalam pijat bayi terdapat unsur sentuhan berupa kasih sayang, perhatian, suara, pandangan mata, gerakan dan pijatan. Stimulasi ini akan merangsang perkembangan struktur dan fungsi sel-sel otak (Maharani, 2009).

Keuntungan pijat bayi adalah mampu menjalin kasih sayang dengan orang-orang terdekat yang memijat, memacu sistem sirkulasi darah, jantung, pernafasan, pencernaan dan sistem kekebalan tubuh bayi dan anak, yaitu menurunkan adrenalin dan menaikkan corticosterois sehingga bayi akan tenang dan kekebalan tubuhnya akan meningkat, melatih bayi untuk lebih tenang dalam menghadapi stres, juga mendorong pertumbuhan susunan otot dan kelenturannya (Pratyahara, 2012).

Berdasarkan data yang didapatkan di Laporan bulanan Puskesmas Ganjar Agung bulan Juli Oktober 2016 didapatkan bahwa rerata bayi yang tidak naik berat badan sebesar 14,7\%. Artikel ini dari hasil penelitian yang bertujuan mengidentifikasi efektifitas pijat bayi terhadap peningkatan berat badan pada bayi di wilayah Puskesmas Ganjar Agung Metro Barat Tahun 2016.

\section{Metode}

Penelitian ini merupakan penelitian kuantitatif dengan rancangan pra eksperiment, non equivalen control group design. Rancangan penelitian digunakan untuk mengetahui peningkatan berat badan bayi sesudah diberikan perlakuan pijat bayi yang dilakukan pada bulan April 2018. Populasi penelitian adalah seluruh bayi yang berusia 0-3 bulan berjumlah 67 bayi. Berdasarkan ketentuan besar sampel sederhana dalam Sugiono (2010) jumlah sampel penelitian ini adalah 25 bayi (Sugiono, 2010). Teknik pengambilan sampel menggunakan consecutive sampling. Sampel penelitian diseleksi dengan kriteria inklusi dan kriteria eksklusi.Kriteria inklusi penelitian ini, yaitu bayi dengan berat badan 
>2500 gram dan bayi masih diberikan ASI eksklusif. Sedangkan, kriteria eksklusi penelitian terdiri atas bayi demam dengan suhu tubuh > 37,5 dan bayi ada cacat bawaan.

Pengumpulan data dilakukan setelah dilakukan intervensi menggunakan cara observasi dengan menimbang berat badan bayi. Perlakuan atau intervensi kepada responden dengan memberikan pemijatan pada bayi rutin setiap 3 hari sekali masing-masing 15 menit. Pemijatan dilakukan dengan berkunjung ke rumah Responden. Pengukuran dilakukan setelah pemijatan bayi selama 1 bulan atau 30 hari. Pemijatan bayi dibantu oleh 2 enumerator yang sebelumnya telah diberikan pelatihan. Hasil pengukuran dilakukan analisis data univarit menggunakan nilai mean (rerata). Sedangkan, analisis bivarit menggunakan uji paired $t$ dengan tingkat kepercayaan 95\% dan tingkat kemaknaan $(\alpha) 0,05$.

\section{Hasil}

\section{Rerata berat badan bayi sebelum dan sesudah dilakukan pijat bayi}

Hasil penelitian pada tabel 1 memperlihatkan bahwa rerata berat badan bayi sebelum diberikan pijat bayi diperoleh 4,4 kg dengan 95\% CI: 4,11-4,85 dengan standar deviasi 0,8. Berat Badan Bayi minimal 3,2 kg dan maksimal 6,4 kg. Estimasi interval dapat terlihat bahwa 95\% CI rerata berat badan bayi adalah diantara 4,1 - 4,8 kg. Sedangkan, setelah diberikan pijat 30 hari rerata berat badan bayi sesudah diberikan pijat bayi diperoleh 5,4 kg, dengan 95\% CI: 5,40-5,02 dengan standar deviasi 0,9. Berat badan bayi minimal 4,0 kg dan maksimal7,4 kg. Estimasi interval menunjukkan bahwa 95\% CI rerata berat badan bayi adalah diantara $5,4-5,0 \mathrm{~kg}$.

\section{Rerata kenaikan berat badan bayi sebelum dan sesudah diberikan pijat bayi}

Tabel 1 memperlihatkan rerata selisih berat badan bayi sebelum dan sesudah diberikan pijat pada bayi adalah sebesar 0,916 kg dengan standar daviasi 0,12. Hasil analisis pada tabel 2 menunjukkan terdapat perbedaan berat badan sebelum dan sesudah dilakukan intervensi atau terdapat efektifitas pijat bayi terhadap peningkatan berat badan bayi $(p=0,000 ; \alpha=0,05)$.

Tabel 1.

Distribusi Rerata Berat Badan Bayi Sebelum dan Sesudah IntervensiPijat Bayi

\begin{tabular}{lccccc}
\hline \multicolumn{1}{c}{ Berat Badan Bayi } & n & Mean & SD & Minimal-Maksimal & 95\% CI \\
\hline Sebelum diberikan Pijat Bayi & 25 & 4,484 & 0,886 & $3,2-6,4$ & $4,118-4,850$ \\
Sesudah diberikan Pijat Bayi & 25 & 5,400 & 0,912 & $4,0-7,4$ & $5,400-5,023$ \\
\hline
\end{tabular}

Tabel 2.

Rerata Kenaikan Berat Badan Bayi Sebelum dan Sesudah Intervensi Pijat Bayi

\begin{tabular}{cccccc}
\hline Variabel & n & Mean & SD & SE & P value \\
\hline $\begin{array}{l}\text { Berat Badan bayi } \\
\text { sesudah Intervensi }\end{array}$ & 25 & 0,916 & 0,121 & 0,193 & 0,000 \\
\hline
\end{tabular}

\section{Pembahasan}

\section{Rerata berat badan bayi sebelum dan sesudah dilakukan pijat bayi}

Pijat bayi merupakan aplikasi stimulasi sentuhan yang dapat merangsang perkembangan struktur dan fungsi sel-sel otak dan meningkatkan berat badan (Maharani, 2009). Hasil penelitian ini yang dilakukan terhadap 25 bayi usia 0-3 bulan menunjukkan peningkatan berat badan bayi setelah diberikan pemijatan 30 hari. Rerata berat badan bayi sebelum diberikan perlakuan adalah sebesar 4,484 $\mathrm{kg}$ dan setelah diberikan perlakuan terjadi peningkatan dengan rerata berat badan bayi menjadi $5,400 \mathrm{~kg}$ atau terjadi peningkatan rerata berat badan bayi $0,916 \mathrm{~kg}(\mathrm{SD} 0,1214)$ setelah diberikan pijat. 
Sentuhan merupakan salah satu jenis stimulasi. Jenis-jenis stimulasi dapat berupa stimulasi visual, pendengaran, kinetik dan sentuhan. Stimulasi sentuhan yang selama ini diberikan masyarakat kepada anaknya adalah dengan sentuhan atau pijat. Berat badan bayi menjadi 2 kali lipat berat badan lahir pada akhir 6 bulan pertama (Irva \& Hasanah, 2014).

Hasil penelitian yang dilakukan oleh Prof. T. Field dan Scafidi tahun 1986 dan 1990, menunjukkan bahwa pada 20 bayi prematur berat badan 1.280 gram dan 1.176 gram, yang dipijat $3 \mathrm{x}$ 15 menit selama 10 hari mengalami berat badan per hari $20 \%$ sampai $47 \%$ lebih banyak dari yang tidak dipijat (Roesli, 2011). Terjadinya perbedaan peningkatan berat badan yang lebih tinggi pada bayi, karena pemijatan pada bayi merangsang saraf vagus, yaitu saraf kranialis kesepuluh yang sebagian besar saraf simpatis, mensyarafi organ dalam termasuk saluran pencernaan, yang meningkatan enzim penyerapan nutrisi dan insulin. Sehingga nutrisi bisa lebih banyak diserap, hal ini menyebabkan peningkatan berat badan bayi akan lebih cepat.

\section{Efektifitas pijat bayi terhadap peningkatan berat badan bayi}

Hasil penelitian yang dilakukan terhadap 25 bayi usia $0-3$ bulan menunjukkan bahwa ada perbedaan yang bermakan peningkatan rerata berat badan bayi sebelum dan sesudah dilakukan pemijatan ( $\mathrm{p}$ value 0,000 ). Rerata berat badan bayi sebelum diberikan perlakuan adalah sebesar 4,484 gram setelah diberikan perlakuan mengalami peningkatan, yaitu sebesar 5,400 gram, atau rerata berat badan bayi mengalami peningkatan sebesar 0,916 gram.

Hasil penelitian ini sesuai dengan beberapa penelitian terdahulu tentang efektifitas pijat bayi terhadap peningkatan berat badan bayi. Hasil penelitian yang dilakukan Field tahun 2002 bahwa terapi pijat memberikan efek positif secara fisik, antara lain kenaikan berat badan bayi dan peningkatan produksi air susu ibu (ASI) ( (Field, 2002). Penelitian oleh MuHartini dan Solechan tahun 2014 di SMC RS Telogerojo dengan hasil terdapat perbedaan yang signifikan antara berat badan sebelum dan sesudah diberikan pijat bayi. Hasil penelitian menunjukkan pijat bayi efektif untuk meningkatkan berat badan bayi (Mutmainah, Hartini, \& Achmad, 2016)

Pengamatan terhadap perubahan terhadap peningkatan berat badan 20 bayi prematur setelah dapat pijatan secara teratur. Bayi mengalami kenaikan berat badan 20-47\% perhari setelah dipijat 3 kali 15 menit selama 10 hari. Pada bayi usia 1-3 bulan yang dipijat 15 menit, dua kali seminggu selama enam minggu mengalami kenaikan berat badan lebih tinggi dari kelompok bayi yang tidak dipijat. Pijat bayi akan meningkatkan berat badan. Pemijatan merangsang aktivitas nervus vagus. Penelitian Field dan Schanberg tahun 1996 yang dikutip oleh (Roesli, 2009) menunjukkan bahwa pijat bayi meningkatkan tonus nervus vagus yang akan meningkatkan kadar enzim penyerapan gastrin dan insulin. Meningkatnya kadar enzim penyerapan gastrin dan insulin maka penyerapan nutrien akan lebih banyak. Hal ini yang menyebabkan peningkatan berat badan bayi yang dipijat meningkat lebih banyak dari pada yang tidak dipijat.

Pijat bayi sangat baik untuk perkembangan bayi. Pengalaman pijat bayi pertama yang dialami bayi adalah saat dilahirkan, yaitu pada waktu bayi melalui jalan lahir si ibu. Proses kelahiran adalah suatu pengalaman traumatik bagi bayi karena bayi yang lahir harus meninggalkan rahim yang hangat, aman, nyaman dan dengan keterbatasan ruang gerak menuju ke suatu dunia dengan kebebasan gerak tanpa batas, yang menakutkan, tanpa sentuhan-sentuhan yang aman dan nyaman di sekelilingnya, seperti halnya ketidak beradaan di dalam rahim (Pratyahara, 2012).

Pijat bayi memberikan manfaat yang sangat besar pada perkembangan bayi, baik secara fisik maupun emosional. Banyak penelitian yang menunjukkan bahwa bayi yang kurang bulan yang mendapat pijatan 10 - 15 menit, 3 kali per hari mengalami kenaikan berat badan 20-47\% perhari lebih dari yang tidak dipijat. Penelitian terhadap bayi cukup bulan yang berusia 1-3 bulan yang dipijat 15 menit, dua kali seminggu selama 6 minggu mengalami kenaikan berat badan yang lebih tinggi dari 
kelompok kontrol (Roesli, 2009). Pijat bayi pada dasarnya akan menciptakan bonding attachment dan selain itu pijat bayi dapat meningkatkan berat badan bayi.

Pemijatan juga mengoptimalkan tumbuh kembang bayi dengan risiko tinggi, yakni bayi-bayi yang dalam proses kehamilan dan kelahirannya mempunyai faktor-faktor risiko yang dapat mengganggu tumbuh kembangnya. Misalnya, berat lahir kurang dari 2.000 gram, tidak langsung menangis, biru, kadar bilirubin tinggi, sering kejang, dan mengidap penyakit atau gangguan kesehatan lainnya (Narendra \& Soetjiningsih, 2008). Perlunya ibu-ibu yang mempunyai bayi untuk melakukan pijat secara rutin yang dapat bermanfaat untuk meningkatkan berat badan bayi secara optimal.

\section{Simpulan dan saran}

Simpulan penelitian menunjukkan bahwa pijat bayi efektif untuk meningkatkan berat badan bayi. Terdapat kenaikan berat badan bayi setelah diberikan pemijatan dengan rerata $0,916 \mathrm{~kg}$. Bidan puskesmas bekerjasama dengan kader kesehatan dapat mensosialisasikan dan melakukan pelatihan pijat bayi secara terus menerus pada ibu-ibu yang memiliki bayi usia 0-3 bulan, agar pertumbuhan bayi dapat secara optimal.

\section{Referensi}

Field, T, 2002. Preterm infant massage therapy studies: an American approach . Retrieved from https://www.sciencedirect.com/science/article/pii/ Doi.org/10.1053/siny.2002.0153 Copyright @ 2002 Elsevier Science Ltd. All rights reserved.

Irva, T.S., Oswati, Rismadefi, H., Woferst. (2014). Pengaruh Terapi Pijat terhadap Peningkatan Berat Badan Bayi 2014. JOM PSIK. 1(2). 1-9.

Maharani, S. (2009). Pijat dan senam sehat untuk bayi. Yogjakarta: Katahati.

Manuaba, I.A.C., Manuaba, I.B.G.F., \& Manuaba, I.B.G., 2015. Buku ajar patologi obstetri untuk mahasiswa kebidanan. Jakarta: Buku Kedokteran EGC.

Mutmainah, M., Hartini, S., \& Achmad, S. (2016). Efektivitas pijat bayi terhadap berat badan bayi usia 0-3 bulan di SMC RS telogorejo. Jurnal Ilmu Keperawatan dan Kebidanan, 8(2) 179-187.

Narendra M., Titi S., \& Soetjiningsih., 2008. Buku Ajar I Tumbuh Kembang Anak dan Remaja. Jakarta: CV Sagung Seto.

Pratyahara, D. (2012). Keajaiban terapi sentuh untuk bayi anda. Jakarta: PT Buku Kita.

Roesli, U., (2011). Pedoman pijat bayi. Jakarta: PT. Trubus Agriwidya.

Roseli, U., (2009).Pedoman pijat bayi. Jakarta: Penerbit Pustaka Pembangunan Swadaya Nusantara.

Sugiono. (2010). Statistika Untuk penelitian. Bandung: CV Alfabeta.

Sunarsih, T. (2010). Pengaruh pijat bayi terhadap kenaikan berat badan bayi umur 0-3 bulan di BPS Saraswati Sleman Yogyakarta. Retreived from Ejournal. respati.ac.id/ diperoleh tanggal 29 November 2014. 